\title{
Economic Reasoning and Its Educational Forms in Turkish Education System
}

\author{
Nurettin Beltekin ${ }^{1, *}$, Yalçın Özdemir ${ }^{2}$ \\ ${ }^{1}$ Department of Educational Sciences, Mardin Artuklu University, Turkey \\ ${ }^{2}$ Faculty of Education, Niğde Ömer Halisdemir University, Turkey
}

Copyright $\odot 2018$ by authors, all rights reserved. Authors agree that this article remains permanently open access under the terms of the Creative Commons Attribution License 4.0 International License

\begin{abstract}
The neoliberal trends which have been become dominant with the 1980 s caused the reconstruction of all social areas, especially economy. The World Bank who is the global actor of the neoliberal policies is the object of this reconstruction processes in especially east societies. The economic reasoning is the main subject of this processes has been tried to be hegemonic in the educational fields too. In this paper, it is tried to indicate the educational forms of economic reasoning by examining the Turkish education system after 1980's. The economic reasoning is a thinking form which aims to price everything. Its main aim is to make fenomens suited for the pricing. In the other words, the main aim of economic reasoning is to make everything subject of market. Because material things' weights, lengths and volumes are measurable, it is easy to make them suited for pricing. But when someone try to do the same thing for educational institutions and educational labor, it is not easy. So in this study, we tried to show how the economic reasoning deal with this problem. In other words, we tried to find out how pricing and marketization processes have been realized by examining of curriculum, private schools, autonomy of schools' budgets, tuition fees, educational quality and performance evaluation.
\end{abstract}

Keywords Economic Reasoning, Educational Forms, Pricing, Marketization

\section{Introduction}

\subsection{Economic Reasoning}

Economic reasoning with its narrow sense indicates a specific kind of thought and people move in accordance with this kind of thought. Therefore the intelligibility of economic reasoning requires the intelligibility of this human being's characters conceptualized as "homo economics" by the discipline of economics. If the truth that people aren't living that is independent from environmental circumstances is accepted, it is sayable that it is the certain social condition which make homo economics who is supposed to be rigged with this reason possible. In this context, economic reasoning can be interpreted as outpouring of a specific social formation (capitalism).

Economic reasoning, on the other hand, bears the trace of the dominant economical approaches and the discipline of economics that puts "homo economics" whose behaviors are presumed to be dominated into the scientific literature, and that even owes the knowledge it generates to economic reasoning and homo economics that is posited to have this reason to a large extent. Herewith, economic reasoning may be defined as the reification of epistemological and methodological admission of the dominant economics. However, economic reasoning is directly associated with the discipline of economics that justifies free market, capitalism and the knowledge of capitalist production, it shouldn't be conceived as a notion that is only analyzed by discipline of economics or a notion related to economic facts. When the potency of economics that ensures the other social sciences which is enounced as the delineation of economics imperialism in today [1], it is to be stated that economic reasoning is also used to describe human being that is an analyze object of other social sciences ever after. In other saying, today, various social sciences disciplines widely apprehend the human being that is an analyze object as a living behaving according to the principles of economic reasoning, and lean their analysis on him. For example, in sociology discipline, the conceptualization of economic reasoning both requires and reproduces the conception of "the society as the total of human beings having economic reasoning and behaving in accordance with this reason". Similarly, economic reasoning is being conceptualized as the rational human being that labor to increase human capital within educational sciences and via especially the discipline of education economy, and this assumption can be based on in many educational policies ranging from educational 
financing to planning. Thereby, when it is taken into account that the dominant scientific approaches in today substantially produce the ascribed social structures and power relations that would be right to interpret the conceptualization of economic reasoning not only as an academic argument but also in the context of ruling practices.

Hereby, economic reasoning may be defined as a notion indicating a certain way of thinking, a certain human being type behaving in accordance with this way of thinking, the capitalist social formation and capitalist applications that provide this type of human being to come to exist, the epistemological, ontological and methodological admissions playing a crucial role in the reproduction of capitalist social formation.

Although the fact that the way of economic thinking [reasoning] is rested within the western intellectual history is an argument that typically gains acceptance [2], the whole realization of this reasoning has taken place with industrial capitalism. In the meantime, the enforcement of economic analysis and economic reasoning upon the other social sciences; especially law, policy sciences and sociology has been getting intensified for the last three decades [3]. However, the date of the indicated facts by being associated with the western intellectual history has been based on ancient times, it is possible to say that the conceptualization became apparent with the work of Andre Gorz bearing the name of "Critique of Economic reasoning". According to Andre Gorz working through the conceptualization of economic reasoning in the context of gainful occupation [4], the liberation of economic reasoning from the other rationality forms repressing itself provides industrial capitalism to leap forward. In other words, to Gorz, the fact that the social conditions enable the human being having economic reasoning to utilize this way of thinking outright is capitalist social formation. While Gorz [4] states that reckoning and computation performance that almost backdates with history of humanity is the prerequisite of economic rationality, he remarks that economic rationality doesn't realize itself by the reason of the fact that it is repressed by the other rationality forms till the development of industrial capitalism. To Gorz, the most crucial factors preventing economic rationality from realizing itself are the feudal social formation enounced as conventional order by Gorz, and internal and external limitations imposed by rituals and imperatives [4]. Hereby, Gorz [4] considers economic reasoning and capitalism equal with his statements as "Capitalism is the the signification of economic rationality that throws off all the ties", or defines economic reasoning as the philosophical essence of capitalism in a way.

Wentworth [5] states that economic reasoning basically includes some prerequisites related to human behaviors, and the methodological attitude as deductive line of reasoning of economic discipline using these prerequisites. The thoughts-attitudes and behaviors indicated by economic reasoning can externalize themselves through homo economics. These characteristics describing economic reasoning appealingly are also basic assumptions that the discipline of economics builds the knowledge on it. Therefore the typology of homo economics and thereby economic reasoning is described as a milestone that economic theories are built on [6].

Alike the other social sciences, the discipline of economics utilizes the methods of natural sciences for the sake of gaining admission as a scientific discipline for its establishment, and adjusts its general admissions pertaining to nature to society and human being. Adam Smith who is one of the founder of economic discipline acting according to order (nature laws) hypothesis assumed to exist in nature attributes the thing regulating the system in society to the invisible hand that is a consequence of the behaviors of economic man defined homo economics by him [7]. According to homo economics assumption taking place both in classical and neoclassical theory, human beings seek after benefit and the firms founded by human beings seek after profit [8]. As seen here, homo economics and thereby economic reasoning become a notion referring to these structures in order to analyze the various structures made by human beings as stated in firm example rather than being only a description related to a nonphysical human being. Another assumption deductively posited as a fact by economics and coming along with the assumption of homo economics is the fact that natural resources are exiguous. In other words, the conceptualization of economic reasoning and homo economics having it includes the admissions not only associated with human beings but also nature (the shortage of resources). Due to the resources assumed as exiguous, homo economics is described as result-oriented living aiming at the most benefit or profit and the least inconvenience and cost by making rationalist choices [9]. Thus, by looking at a way of thinking and human being having this way of thinking, not only the small structures as stated in firm example but also presuppositions and delineations with respect to nature and even social structure may be attained. For example, Kizilkaya [10] states that the typology of homo economics is also fictionalized as an entity asserting rational choices against exiguity and moving in the direction of founding social order within the frame of market system. In this sense, it is stated that economic reasoning and homo economics defined with economic reasoning that is accepted by dominant economic theories is irrevocable in the context of fictionalizing capitalist system [10] With his journey from classical economics to neoclassical one, homo economics has become an analytical tool for output forecast and a self-centered model providing the utility-maximizing with its finite resources anymore [6].

Economic reasoning emphasizes particularly to the economics of human behavior and in general to the rationality of it, and it even presents an intellectual framework in which rationality is reduced to economic 
rationality. Zafirovski [11] states that the thing summarizing this intellectual framework is the understanding of rational choice. The rational behavior reached through the guidance of economic reasoning is equalized with economic reasoning. As for the content it is reduced to profit maximization for the producers and benefit maximization for the consumers. Zafirovski [11] emphasizes that the rational choice approach moved by the equality of rational and economic behavior is adapting this link to all human behaviors. In other words the economic reasoning is increased to an analytical tool that would define all human behaviors not only the human behaviors related to the economical phenomenon.

We can find one of the interesting examples of this approach criticized by Zafirovski in Kourilsky and Kehret-Ward's study [12]. The authors [12] have developed an "economic reasoning scale" to be able to measure the economic reasoning which they define as a decision making hierarchy consisting of famine, alternatives and opportunity cost. According to the authors the actual thing drawing economic mind is benefit-cost analyses. Therefore, an individual performing benefit-cost analysis in any context and performing his actions through the rational choices made in the direction of this analysis can be described as having. The statements of Gorz that economic reasoning would require quantification are meaningful in this context. Even in the case that it is the emotions that become a subject to be analyzed benefit-cost analysis will require digitization and as a result quantification. Gorz, [4] cites that to make it calculable the quantified economic rationalization is removing all the criteria that would allow it to be satisfied with what is possessed, built or planned to be committed. This finding of Gorz can also be associated with positivist science paradigm. In the case of positivist paradigm a distinction is done between "what happened", and "what is supposed to be" and it is claimed that science should only deal with what happened not with what is supposed to be. So in positivist paradigm phenomenon-value separation is done. It can be stated that the meaning that the dominant economic approaches ascribe to the economic intelligence is on the same level with positivism. For example Robbins [quoting: 6] defines the economic intelligence as a neutral process which is independent from all kinds of values and he claims that it should mean that economic intelligence and as a result the economy itself are associated with what happened more than what is supposed to be. In other words, in the scientific analyzes which move with the acceptance of economical intelligence the social analyzes such as equality, justice are easily excluded from the scientific analyze with the justification that they are "ideological". According to Gorz [4] the economical intelligence which seems to be free from value and objectivity of which has been highlighted by the numbers and the mathematical models constructed from numbers is also becoming something that cannot be examined and criticized with the same reason. Despite the fact that, positivism which poses an unquestionable armor to economic intelligence emphasizes to the objectivity the aim of the economic intelligence is the maximization of productivity that can be measured through calculations and with the profit rate as a basic indicator [4].

Together with this quantification the understanding and acceptance towards everything can be calculated also constitute the general condition of dominant economic analysis and mathematical models based on economic reasoning in other words the spread of dominant economics towards other social sciences [3].

By stating that the instrumental mind included in the economic intelligence draws the general framework of the modern industrial society Man [13] conveys the expression of Gaulejac which is cited within this framework as the motivation of " instrumental mind" which has been resulted in modern societies to be considered as an enterprise (or venture) with all its institutions. As a result today it can be stated that at the basis of the neoliberal politics lies the hypothesis of economic intelligence. Subjecting all the actions of human being to the economic intelligence is preparing for further implementations, such as quantification, quantifiable, subjecting to calculations and foretelling, which are more than being just an academic argumentation as mentioned before. Today it can be claimed that the performance evaluations of economic intelligence is representing the hypothesis lying in the base of many power implementations which are expressed to aim the rationalization in bureaucratic institutions [14] through the total quality management, strategical planning, good implementations etc. Similarly the rationality that is supposed to be drawn by the economic intelligence supports also the position that in the social politics fields it is unnecessary to protect humans against the result of their own preferences [15]. In other words, the assumption of the economic human presumed to have a capacity to rationally choice through economic intelligence is the basis for the erosion of the state's conservative social policies and the implementation of many neoliberal policies. Because by using the reason human being acting on benefit/cost analysis is trying to maximize his/her own maximization and thus the benefit of society accepted as the sum of individuals is also increasing and as a result no need for state to exist anymore.

\subsection{Educational Forms of Economic Reasoning}

While economic reasoning within educational reality on one hand changes the meaning given to the education, on the other hand makes its effect gradually felt on forming educational processes from educational financing, planning to management. It can be said that the effect of economic reasoning on educational reality has considerably been seen with 1960 's. [16]. The process that has started from this date on, the center countries giving 
supply-side grant and credit to periphery countries has widened by surrounding educational areas. Social assistance and grants that especially started in 70's and 80 's have conditionally been carried out. The World Bank, one of the important institutions of center countries, has managed this process.

It has been seen that economic reasoning once again has defined the aim and the value of education. While Education at common traditional education perception seen as a free service producing meaning and value on behalf of society and economy is only one of the functions of education, in the new process education has been started to be shaped by economical aims and sensitiveness. In fact, education has turned into one of the components of production function of projects carried out by credits that The World Bank has conditionally given to periphery countries as a part of progress paradigm. As a meaning and value instead of education, it has been tried to be defined once again on its contribution to production function. Education's change value that gradually commodified with Özsoy's statement, [17] has started to gain importance.

In education, the coincidence of the date of economic reasoning's effect been seen and the date of educational economy's foundation is remarkable in this respect. The foundation of educational economy has simultaneously come out with human capital theory one of the most important type of education in economic reasoning. Gary Becker one of the people made the most important contribution to Human Capital Theory in his study named (HCT), "Human Capital: Theoretical and Experiential Analysis with Special Reference to Education, by clearly stating that analysis depend on the idea that " all people are rational", has stated that education is an important and profitable investment with the expression of " being rational" "..... is to choose a way that maximize the value of profitability [16]. So it can be expressed that HCT has remarkably been used in shaping educational aims. With intensified economical approaches on education, education's social functions have gradually been forgotten or beside education's economical functions, it has been pushed background, and they tried to train individuals whose aims shaped by economic reasoning and who can use their economic reasoning through education [18].

Most of economist thinks that the core of economical approach related to education is manpower planning [19]. Economic reasoning has directed social scientists and social policies on subjects as educational economy should take training in the context of a discipline and when to take the training [1]. Becoming marketable and commercialization applications in education have gained speed especially through neoliberal policies carried out after 1980's. On the other hand putting forward education's role in the context of labor power producing again has shown itself as professionalization in secondary education and in higher education the weight on applied sciences.
While on privatization financing has been left on rational individuals, in the planning of education over cost-benefit analysis professionalization has come forward. On the other hand, economic reasoning has accelerated the mutation of educational processes. Rational and selfish economical human hypothesis has eased the interpretation of education on competition, the meaning of education has been tried to be find out on numbers that measured quantified by central exams.

The interpretation of the quality of education service is also not free of quantification. The labor of education laborers has been tried to be managed over by interpreting performance criterion, education laborers, (performance awards directed to teachers and academician etc.) have been tried to be motivated over performance criterions. But this process can also be described as unsecured face side of working for education laborers.

\subsection{The Aim of the Research}

The aim of the research is to analyze the processes of liberalization that started after 1980 with the help of their reflections on education in Turkey society which doesn't see economic reasoning's forms paid traditionally.

\subsection{The Method of the Research}

As the research wants to analyze economic reasoning's educational forms from the transformation in Turkish education system, case study techniques, which enable this, has been benefited from. Case study is a quite detailed examination of the past of a social unity, its present state, and relational qualities with its environment [20]. As data collection tool education applications, and documents related to applications in question have been used. In this subject, the uses of primary documents have been cared. Documents are generally formed of Ministry of Education's documents related to transformation, researches done over these transformations and application reports.

In the analysis of data by watching the aims of the actors in education transformation, the different forms of economic reasoning over educational areas have tried to be detected. In the research Turkey's transformation parallel with liberalization in the World after 1980's has been examined in the field of education. In the study, applications evolved from paid to free or paid or sensitization to economy forms have been concentrated on. In this context, in the process after 1980 the transformation in education policy, private school, private courses, the foundation of private universities, localization of schools, in other words autonomous budget applications at schools, students' contribution margins and performance evaluation applications have been watched. As a data collection tool documents related to this period have been benefited. 


\section{Findings}

\subsection{Education Sensitive to Economy}

Education is not an area seen as subject of commerce in many societies. For example, science in Muslim societies has been seen as worship and a mean of intimacy to God in Islam belief. The idea of seeing this activity a mean of commerce and getting payment in return hasn't been accepted by Muslim scholars [21]. Yet, in Turkey since the establishment of Republic, the area of education has developed as a public space. One of the most important expressions that Republican educations use in Turkey is the claim of free equal education for everybody. This thought has caused education to be understood as a service that presented free to everybody under the protection of government. Religious and political tradition of Turkey has become a big obstacle in front of perception of education and commerce together.

Despite with the liberalization process in economy that started with January 241980 like many other areas, education area has been opened to private enterprise in other words seeing education as a meta has been led up. In spite of the society' big indifference to this new expansion, within the reform studies in education that started after 1990 , it is possible to see an emphasis sensitive to economy in justifications stated by Board of Education and Discipline in new primary education program. These justifications are [22];

- An education need that is sensitive to economy and democracy,

- Scientific and technological developments,

- Developments in Educational Sciences' teaching/learning understanding,

- The need of increasing quality and equality in education,

- The need of developing individual and national values inside global values,

- The need of providing programme integrity for eight years of primary education,

- The necessity of providing conceptual integrity cross-curricular in horizontal axis and each lesson's having conceptual integrity in its vertical axis.

- PISA, TIMMS, PIRLS etc. research results are lined in a hopeless way.

When with the need of global capitalism the justifications in question dealt with, the politicization of the reforms which presented as "necessity and obligation", show up clearly. The need of providing satisfaction needs of manpower quality that appeared as a need of the transformation of market and has always changed is a costly job for market actors. This job is loaded on state schools with "An education sensitive to economy." Doing this starting from primary education will enable the production of necessary qualities at lower education forms and levels. While the manpower that market needs provided with employment of higher education people before; so at primary education competitiveness, entrepreneurship, compatibility with team work, creativeness, While the manpower that market needs provided with employment of higher education graduates; so in primary education this will be chosen from individuals studying vocational education and acquiring qualities as competitiveness, entrepreneurship, suitability with team work, creativity. For example, with employing graduate of vocational high school's electrical department instead of a more costly electrical engineer, manpower cost will be reduced. Capitalist classes' primary education emphasis and "vocational high school national matter" slogans can be evaluated in this frame.

This process in fact is a sign of internalization of economic reasoning's cost/ benefit analysis by education area. The determination of education content by economical needs resulted in educators shaping education type and level in the context as mentioned. Yet the project that mentioned above Vocational High School National Matter (VHSNM) has been prepared by Koç Holding, one of the important marketing actors of Turkey, and Ministry of Education. The aim of VHSNM is based on "mobilization for the solution of our country's problems as unemployment and qualitative manpower needs." It has been stated that the project has been designed to put vocational education in the center for solutions of these problems, by creating awareness in public opinion about the problems that vocational and technique education face, activate related shareholders for the solution of the problem and contribute to qualitative manpower by strengthening vocational high schools' reputation" [23]

This process which can be stated as professionalization of education in secondary education in fact goes back to older dates. With "Education Project " that Turkey signed with World Bank in 1971, providing materials for 12 technical school and 12 commercial school; with “ Industrial Education Project" that signed in 1984, increasing the productiveness of workers working in manufacturing export; with "Industrial School Project" signed in 1995, increasing the number of industrial manpower; increasing the planning administrative and capacity of General directorate of Technical Education for Boys; with " Non-formal Vocational Education Project" signed in 1987, it helps increasing the demand for manpower trained through non-formal vocational education and strengthening the capacity of intuition that responsible for this education [24]. These projects can be seen consequences of preferring forms and levels of education that are more useful.

The aims of "Industrial Education Project" - II, signed in 1988, described as; strengthening the The Council of Higher Education's planning and coordinating capacity regarding technician education programme and vocational and technique teacher education programme, improving 
technicians instructed in industry sector in terms of quality and increasing their numbers, and increasing the demand for instructed vocational and technic teachers [24]. With these and similar projects signed with The World Bank, Higher Education's economic character has been done more hegemonic. Thus as a result of this process the closure and being second of "Basic Sciences" which are basic areas for universities, is observed [25]. But in the periods of student admission, it is seen that basic sciences can't find students and their quotas loafed about. In spite of the university-industry cooperation projects that applied sciences put forward have been supported, and important budgets have been reserved.

An education sensitive to economy, in other words, it is possible to see strengthening educational reason for sixteen years in expressions of conservative policies that in power. But one of the Minister of Education İsmet YILMAZ has stated that "Turkey doesn't have riches like petrol and natural gas, its biggest richness is its human capital." [26]. Human being described as capital is one of the discursive forms of human capital ideology. Human being counted as capital like petrol and natural gas is not anything else from the rationalization of economic reasoning.

\subsection{Sectoring of Education}

One of the expressions of economic reasoning about public administration is expressed as a public administration is harder, bureaucratic, and unproductive as to private sector. The expression that with the minimization of the state, a small and an active state will be gained, has largely been accepted in Turkey after the period of 1980 . They have for instance, alleged that the state's being monopoly in some areas like education, reduced the quality of goods and services, with these kinds of goods and services getting into the market many companies/organization's will get into the field and rivalry will both increase the quality of goods and services and will reduce their price. As a result firstly state economic enterprises, many institutes belonging to the public have been privatized.

Despite of allowing private sector get business in education field in Turkey with 1980, the increase in private schools has quite slowly proceeded until recent times. Education's not being a paid area in social culture can be the reason of this slowness. In contrast to this, the success diagram of private schools, the success of students' getting into higher education, cultural and sportive facilities and features like security have separated them from state schools. No doubt, the understanding of the qualities that provided this separation have a cost, has taken place in society. Some students' parents have found it right sending their children directly to private school instead of sending them to state school and sending them to private courses or make them have private lessons to get higher education. The quality difference that appeared between state school and private school, has improved the idea that in time, education will be paid. But this doesn't accelerated the numerological improvement of private schools. Because of government incentive related to private schools in 2001, there has been an increase in the number of students continuing private schools. According to the data of Ministry of Education [27] the number of students continuing to private schools in "2017-2018 academic year has reached to 1 million 300 thousand with an increase of 13 percent compared with last term. The share of private schools in education has reached to 8 percent. While the number of the students going private schools was 1 million 150 thousand, with 13 percent of increase in 2017-2018 it has reached to 1 million 300 thousand. The share of private schools in education in Turkey has risen to 8 percent. So "education sector" has come out. Because" investors" have discovered that education and its achievements are profitable goods and service that can be bought and sold.

Although Turkey's basic law describes education as free students and their parents undertake many education expenses. It is possible to say that these expenses diversify in time. In this frame, detected entertainment expenses, clothing expenses, transportation expenses, internet cafe expenses, sheltering expenses, university canteen expenses, cafe expenses, heating expenses, film hiring expenses, telephone expenses, electric, water, gas expenses, sport expenses, food and drink expenses, spa expenses, cinema expenses, university meal expenses, magazine expenses, concert expenses, book expenses, photocopy expenses, newsagent's expenses as notebook, pencil, eraser and education expenses as in theatre in fact shows that there is a huge sector. Yet many education stuffs and consumable materials that Ministry of Education provided from public institutes like state supply office from now on started to be provided from markets through bids. Naturally, it caused several new companies entering to education sector and lead to increasingly diversifying in goods and services and growth of the "sector".

One of the important necessities of being a sector is administrative flexibility. Administrative flexibility, which is a business management and feature and increasing business compatibility skill against market variability, has moved to school management. School autonomy signifies the power of deciding in schools' being flexible, educational aims, staff, fund-raising, or setting aside, curriculum, financing, and in subjects as gathering students [28]. In the present case school autonomy includes the processes of school management's organization of teaching, staff management, planning, and organization and creates resource/fund. This situation brings big changes at school in the turn of deciding and methods. According to this principals, teachers, families or more person that includes society's members become local decision makers. Besides principals and teachers, families and members of society have a voice in subjects related to education as planning the curriculum, forming academic 
standards, evaluating students, choosing school materials, providing school security, employing staff and evaluating the staff [28].

It is very difficult for Turkish Education System, which has a strict central structure, to internalize school autonomy feature. Especially it is seen impossible to do curriculum, employment of staff, and evaluation of staff by school society members. In spite of the system easily tolerate budget autonomy. Because school autonomy brings schools' doing their budgets themselves with it, in other words, it also brings affording education expenses by school with it. Moreover parents' attendance to education teaching process as actors caused doubling in education expenses. Parent-teacher associations in Turkey have turned into one of the important income items. In addition to this in Turkey except from central budget, some legal or practice items are created to provide budget for schools. For example, renting rural schools to farmers for agriculture product plantation, in cities using school gardens as car park, renting gyms or activity halls for activities as meeting, engagement or wedding that provide income are activities commonly seen to bring income.

\subsection{Teaching Programs}

One of the important reform fields in education after 1980 is teaching programs. In this period teaching programs have been reformed several times. Andrew Vorkink the actor of reform who is the World Bank's Turkey director in his presentation titled "Education Reform in Turkey" has described the aim of new program as Turkish education system trying to reach Europe and raising workers who can compete in the rapidly changing World [29].

One of the teaching program reforms in every type and level is to make students have knowledge, skills and attitudes that the new carrier of economic reasoning neoliberal transformation needs. New skills that should be in the new program and business World needs have been summarized by Vorkink [29] in these titles:

- Expert thinking: There aren't Rule-based solutions to solve problems among them skills as research skills, scientific thought, and diagnostic skills are counted.

- Complex communications: Getting information, explaining, or communicate with others to convince them regarding the results of an action and among them convincing correspondence, management of staff, legal correspondence, advertisement, marketing and sales are counted.

- $\quad$ Routine manual duties: Physical duties that are well defined by applying the rules as counting medications, packaging, and repetitive montage. There is decrease in these duties.
- $\quad$ Routine cognitive duties: Mental duties that well defined by applying logic rules, Keeping expense reports, keeping accounting reports, repetitive customer service, like bank attendant. ( these duties increasingly can be computer-based done so the needs decrease)

- Nonroutine manual duties: "If so,- so happens" rule-based works as this can't be defined relatively simple physical works for example, cleaning services, lorry driver, passenger transport charts. Demand for this kind of cheap works that require low skills will continue.

As seen in Vorkink's expression the knowledge, skills and behaviors that students need to gains have been determined in accordance with business world's needs independent from students' educational needs. Here clearly a contact has been made between high productive manpower, country's competitiveness and a natural result of it, development and enrichment of the country. Economic reasoning has rationalized itself with expression of progress and enrichment. Yet, in the next period it is clearly possible to see it in the texts of politic actors.

For example, the ruling party's 2018 election programs describe education as an investment [30], to promote students to vocational high school "We will incentivize the employment of vocational and high school graduates. We will popularize the application that we started to set vocational high school in organized industrial site. We will improve vocational and technique education school management model, and we will provide the attendance of local government and sector agents." expressions as this have taken place. In fact these expressions aren't anything else except from marketing actors' demands for education. One of the hegemonic forms of economic reasoning is to do marketing actors one of the shareholders of education area. As seen specific to teaching programs, the field has been shaped in the direction of both international marketing actor as World Bank and national marketing actors.

\subsection{Quality and Performance Evaluation in Education}

Separation of things or works in equal units that enable settlement of economic reasoning is in other words quantification of it. Studies of total quality and evaluation based on performance which is one of the biggest efforts of Ministry of Education's after 1980 in Turkey can be evaluated in the context of quantification Whole term quality and performance have turned into one of the main irreplaceable subjects. Yet AKP in 2018 election bulletin has made sentences about the subject of quality as "The subject of quality will be the primary field we give priority to reach these aims. We will start quality mobilization in education. By setting quality assurance system up in education, we will determine high standards for every level of our education and every kind of schools, we will form 
"Education quality index" that include all the schools around the country. We will minimize quality difference between schools. Our education investment will continue by focusing on quality" [30].

The concept of quality that belongs to business management is described as " control applied, the most economic, producing the most useful and always the most satisfactory products for customers, designing it, producing and giving service after sales." [31]. Total quality management is a kind of management which describes quality as "suitability with the aim" and whose aim is "customer demands" [31]. This understanding, which see the quality as the total contribution of whole business units, depends on constant controlling approach of contribution of units. Naturally it is regularly needed to measure the contributions of business units.

Yıldız and Ardıç [32] states that for education institutes that apply total quality in education, setting the system of constant evaluation and collecting data related to quality, reporting them has big importance for raising the quality. In education institutes three kind of evaluation are mentioned: Foreign customer satisfaction index in education institutes (customer satisfaction index, CSI), internal customer satisfaction (employee satisfaction index, ESI) and other quality evaluations related to education institutes' internal processes. Education's being measurable makes it gain the feature of to be priced.

With "National Quality Movement Goodwill Manifesto" that Ministry of Education signed with KalDer, the studies to pass TKY in Ministry of Education have been started. The application of TKY in the field of education have been started with Curriculum Laboratory Schools (CLS) Project that financed by The World Bank. It has been decided to apply in all the schools in the direction of "CLS Applications Dissemination Circular" dated to 20.10.1999 and 4244 numbered circular. After that TKY applications have been institutionalized and in this context for application of TKY at schools School Development Management Team (CDMT) has been set up [33].

After OGYE in Ministry of Education performance management system studies, which also accepted to include quality studies, have started. Some studies done by Ministry of Education are below [34]:

- Performance Management System at School EARGED

- Total Quality Management Application Instruction and Award Instruction - General Directorate of Staff

- Supervision and Performance Evaluation Principles - Department of Inspection Board

- Standards of Primary Education Institutes General Directorate of Primary Education

- MEBGEP-Projects Coordination Center Chairmanship

These efforts in fact are to make education institutes and workers studies/ labors measurable by marking their institutional standards and vocational proficiency. Thanks to this with school's price and workers performance points, award and price differentiation will be obtained.

\section{Discussion and Conclusions}

The conceptualization of economic reasoning that includes more than one meaning carries value in terms of understanding the relations between concepts and applications that basically seem eccentric from each other. Within this framework the educational forms of economic reasoning offer an entire approach suggestion related to naming transformation that education has gone through these days. In Turkey, especially after 1980's, as many dimensions of social structure in education there have been sharp transformations too. These transformations have come true in the scale of that can't be limited with the monetarization -privatization phenomenon. Yet an entire transformation towards education is addicted to the transformation of our ontological and epistemological acceptance related to the education and up to success of government's applications that will transform our acceptances. The contribution of science in this transformation which has always been in relation with government phenomenon in the process of modernity shouldn't be ignored. In this context, it mustn't be forgotten that methodological approaches, based on discrimination fact-value, which exclude all kinds of discourse prioritizing equality and justice with accusing of being ideological have a part in transformation in education.

The perception that education's being a tool for gaining better economic conditions and social statue especially has gradually risen with 1980 's. The acceptance increase of this perception in social context is largely related to comprehending education as a tool of social mobility in lower social economic parts of the society. Rather than education's social meaning putting gradually its personal meaning forward and limiting this personal field with only economical one, put forward the relationship between society's gradual atomization and economic reasoning. In this context, with 1980's in Turkey, the development of market relations and the withdrawal of social struggle compared to 1980 's have simultaneously come true.

While with the marketing and privatization education itself at the same time come forward as a quite profitable bazaar for investors, the phenomenon of equality in education has gradually been destroyed against public schools. In this process the share declining of government in public finance has shown its effect in the field of education too and even in public schools personal finance applications stepped in.

The economy phenomenon has especially been used in academic and ordinary language as a concept that cover 
capital concept as "sensitive to economy", "has economic value", "serving to economic progress" and with its emphasis to "education" the meaning and value of education has been conceptualized with only limited context as capital profits. For example, the quality of education service has just only tried to be understood over numbers, service quality and the quality of laborers producing service have been tried to be understood on performance criteria.

Economic reasoning in education is not an eternal phenomenon. Within this framework the deeper analysis of social context that put economic reasoning forward, will be useful in removing toxic effects of economic reasoning. Especially hegemon economic science approaches "self-proclaimed unquestionable methodological approaches" marginalize every critics regarding economic reasoning "in behalf of science". So as well as examining economic reasoning in education and removing this reason's harmful effects. And doing science philosophy discussion will be meaningful.

\section{REFERENCES}

[1] Lazear, E. P. (2000). Economic Imperialism. The Quarterly Journal of Economics, 115(1) 99-146

[2] Pribram, K. (1951). Prolegomena to a History of Economic reasoninging. The Quarterly Journal of Economics, 65(1), $1-37$.

[3] Williamson, O.E. (1993). Calculativeness, Trust, and Economic Organization. The Journal of Law \& Economics, 36(1), Part 2, 453-486.

[4] Gorz, A. (2007). İktisadi Aklın Eleştirisi. Çalışmanın Dönüşümleri/Anlam Arayışı. (Çeviren: Işsk Ergüden). 2. Bask1. Ayrıntı Yayınları: İstanbul.

[5] Wentworth, D.R. (1987). Economic reasoninging: Turning Myth into Reality. Theory into Practice, 26(3), 170-175.

[6] Irene, C.L.NG and Lu-Ming, T. (2008) Learning to be Sociable: The Evolution of Homo Economicus. The American Journal of Economics and Sociology. 67(2), 265-286.

https://doi.org/10.1111/j.1536-7150.2008.00570.x.

[7] İşü̈den, T., Köne, A.Ç. (2002). Ortodoks iktisat üzerine notlar. Doğuş Üniversitesi Dergisi, (5), 97-108

[8] Fidan, H. (2013). İktisadi açıdan bilgi kavramı ve bilgi kavramına yaklaşımlar üzerine bir inceleme. Suleyman Demirel University The Journal of Visionary, 4 (9) 94-104

[9] Soydal, H., Mizrak, Z. ve Yorgancilar, F. (2010). Nöro ekonomi kavramı'nın iktisat bilimi içindeki yeri, önemi ve bilimselliği. Sosyal İktisadi Araştırmalar Dergisi, 10(19), 214-240.

[10] Kizılkaya, E. (2002). Homo Economicus tipolojsinin reddi: Karl Polanyi ve Thorstein Veblen'in iktisada bakış açıları. H.Ü. İktisadi ve İdari Bilimler Fakültesi Dergisi, 20 (2), 73-91
[11] Zafirovski, M. (2003). Human Rational Behavior and Economic Rationality. Electronic Journal of Sociology .http://www.sociology.org/ejs-archives/vol7.2/0 2_zafirovski.html

[12] Kourilsky, M. and Kehret-Ward, T. (1983). Determinants of Economic reasoninging in Monetary and Time-Allocation Decisions: An Exploratory Study. The Journal of Economic Education, 14(4), 23-31.

[13] Man, F. (2013). [Review of the book İktisadi aklın eleştirisi: Çalışmanın dönüşümleri / anlam arayışı by A. Gorz]. İş Ahlak1 Dergisi, 6 (2), 185-192. doi:10.12711/tjbe.2013.6.2 .R005

[14] Akpınar, M. (2014). Max Weber'in rasyonalizasyon (ussallaşma) yaklaşımı ve Türkiye sağlık sektöründe performans sistemi düzenlemesi. AİBÜ Sosyal Bilimler Enstitüsü Dergisi, 14 (2), 189-202

[15] Kahneman, D. (1994). New Challenges to the Rationality Assumption. Journal of Institutional and Theoretical Economics (JITE) 150 (1) pp. 18-36.

[16] Gilead, Tal. (2012). Rousseau, Happiness, and the Economic Approach to Education. Educational Theory 62(3), 267-285

[17] Özsoy, S. (2002). Yükseköğretimde Ticarileşme Süreci ve Hak Söylemi. Özgür Üniversite Forumu, 17, 80-103

[18] Segré, M., Tanguy, L. and Lortic, M-F. (1972). A New Ideology of Education. Social Forces, 50 (3), 313-332.

[19] Williams, G. (1982). The Economics of Education: Current Debates and Prospects. British Journal of Educational Studies, 30(1), 97-107.

[20] Kazak, N. (2001). Sosyal Bilimlerde Araştırma Yöntemleri. Eskişehir: Anadolu ÜniversitesiYayınları

[21] Orhan, F. (2016). İslam Hukuku Açısından Manevî Hak Kavramı. The Journal of International Social Research Cilt: 9 Sayı: 43 Volume: 9 Issue: 43

[22] Milli Eğitim Bakanlığı (2006). İlkögretim Sosyal Bilgiler 4 Ögretmen Kılavuz Kitabı, Dogan Ofset Yayınc1lık, Ankara.

[23] MLMM, (2012) Meslek Lisesi Memleket Meselesi Projesi. www.mesleklisesimemleketmeselesi.com/tr-TR/

[24] Hazine Müsteşarlığı. (2008). Dış Ekonomik İlişkiler Genel Müdürlüğü. Dünya Bankas1 Projeleri Dairesi Web: httpwww.hazine.gov.trmevcutprojeler.pdf-18052008.pdf $18 / 05 / 2008$

[25] Günay, D., Günay, A., Atatekin,E.(2013). Shake in the Basic Sciences in Turkey: The Country's Shake. Journal of Higher Education and Science, Do1: 10.5961/Jhes.2013.06 3.

[26] Y1lmaz, İ. (2017). Türkiye'nin En Büyük Zenginliği Beşeri Sermayesidir. http://www.milliyet.com.tr/bakan-yilmaz-turkiye-nin-en-b uyuk-zenginligi-antalya-yerelhaber-2057979/

[27] Milli Eğitim Bakanlığı (2017). Eğitimde özel sektörün pay1 yüzde 8 'e yükseldi http://www.meb.gov.tr/egitimde-ozel-se ktorun-payi-yuzde-8e-yukseldi/haber/14853/tr. 02.08.2018

[28] Yolcu, H. (2010). Neo-Liberal Dönüşümün Yaşandığı Ülkelerde Yerelleşme ve Okul Özerkliği Uygulamaları. 
ZKU Journal of Social Sciences, Volume 6, Number 12, 2010, pp. 253-273

[29] Şahin-Özdemir, B., Beltekin, N. (2012). Türk Eğitim Sisteminin Dönüşümünde Uluslararası Aktörler: IMF Ve Dünya Bankası Örnekleri. YYÜ, Eğitim Fakültesi Dergisi. 2012, Cilt:IX , Say1:I, 33-55 http://efdergi.yyu.edu.tr

[30] Adalet ve Kalkınma Partisi (2018). Seçim Beyannamesi. www.trthaber.com/pdf/Beyanname23Mays18_icSayfalar.p df

[31] Karaca, E. (2008). Eğitimde Kalite Arayışları Ve Eğitim Fakültelerinin Yeniden Yapılandırılması. Dumlupınar
Üniversitesi Sosyal Bilimler Dergisi, 8, 61-77

[32] Yıldız, G., Ardıç, K. (1999). Eğitimde Toplam Kalite Yönetimi. Bilgi, 1999/1: 73-82

[33] Güçlü, N., Gülbahar, B. (2006). Türk Eğitim Sisteminde Toplam Kalite Yönetiminin Uygulanması. Kazım Karabekir Eğitim Fakültesi Dergisi , 13, 226-239

[34] Beltekin, N., Şahin-Özdemir, B., Yılmaz, G., Akkalkan, H. \& Cemaloğlu. N. (2014). E-performance management system for continuous improvement: A model proposal. Journal of Educational Sciences Research, 4 (Özel Sayı 1), 149-170. http://ebad-jesr.com/ 